\title{
PENGEMBANGAN MATERI TOUR GUIDE DALAM KURIKULUM PENDIDIKAN SEJARAH DI PERGURUAN TINGGI FKIP UNIVERSITAS IVET SEMARANG
}

\author{
Nuryanti \\ Email : Meitasari233@gmail.com \\ Jurusan Sejarah Universitas IVET Semarang
}

\begin{abstract}
Abstrak
Kurikulum adalah seperangkat rencana dan pengaturan mengenai tujuan, isi, dan bahan pelajaran serta cara yang digunakan sebagai pedoman penyelenggaraan kegiatan pembelajaran..Kurikulum merupakan rekayasa pedagogis makro dalam penyelenggaraan pendidikan. Salah satu faktor keberhasilan kualitas pendidikan Indonesia adalah terletak pada kurikulum. Kurikulum pendidikan sejarah pada perguruan tinggi, berkembang seiring dengan perubahan kebijakan kurikulum pendidikan tinggi. Pengembangan kurikulum pendidikan sejarah sangat penting dan harus selalu update untuk menjawab tantangan zaman. Lulusan program studi Pendidikan Sejarah dipersiapkan tidak hanya terjun ke dunia pendidikan menjadi pengajar atau guru sejarah, namun dapat juga menjadi tour guide atau pemandu wisata sejarah. Materi tour guide merupakan salah satu materi pendidikan sejarah yang diprioritaskan untuk mahasiswa lulusan pendidikan sejarah selain menjadi pengajar dapat juga menjadi tour guide/ pemandu wisata sejarah. Permasalahannya bagaimana pengembangan materi tour gude dalam kurikulum pendidikan sejarah di perguruan tinggi. Oleh karena pentingnya materi tour gude untuk mahasiswa maka perlu adanya pengembangan materi tour guide pada kurikulum pendidikan sejarah di perguruan tinggi sehingga dapat memenuhi kebutuhan masyarakat dan tuntutan zaman sekarang.
\end{abstract}

Kata Kunci : Materi Tour Guide, Kurikulum pendidikan sejarah

\section{Pendahuluan}

Pendidikan adalah usaha sadar dan terencana untuk mewujudkan suasana belajar dan proses pembelajaran agar peserta didik secara aktif mengembangkan potensi dirinya untuk memiliki kekuatan spiritual keagamaan, pengendalian diri, kepribadian, kecerdasan, akhlak mulia, serta keterampilan yang diperlukan dirinya dan masyarakat.

Pelaksanan pendidikan haruslah dibarengi dengan kesiapan para pendidik yang dibarengi dengan kemampuan akademik, kompetensi pedagogik dan profesional, serta tanggung jawab yang tinggi dalam mengemban amanah sebagai pendidik. Pendidikan sejarah yang diselenggarakan secara efektif memungkinkan para peserta didk untuk dapat memahami sejarah, membangun kesadaran sejarah, serta pada gilirannya nanti akan dapat membangun karakter 600 | Seminar Nasional Sejarah ke 4 Jurusan Pendidikan Sejarah Universitas Negeri Padang 
kebangsaan. Dengan demikian pendidikan sejarah akan dapat berfungsi sebagai pembangun kesadaran generasi muda untuk mencintai tanah air dan bangsa, mencintai kesatuan dan kesatuan nasional, serta memegang teguh kepribadian nasional sehingga akan memberikan landasan dalam pergaulan internasional yang bermatabat.

Pendidikan Sejarah merupakan suatu proses internalisasi nilai-nilai, pengetahuan, dan keterampilan kesejarahan dari serangkaian peristiwa yang dirancang dan disusun sedemikian rupa untuk mempengaruhi dan mendukung terjadinya proses belajar peserta didik (Kemendikbud, 2013). Hasan(2010) mengemukakan pendidikan sejarah: merupakan media pendidikan yang paling ampuh untuk memperkenalkan kepada pesersta didik tentang bangsanya di masa lampau, mampu mengembangkan potensi peserta didik untuk mengenal nilai-nilai bangsa yang terus bertahan, berubah, dan menjadi milik bangsa pada masa kini, serta berfungsi memperkuat pendidikan karakter.

Ismaun (2005:160-161) menjelaskan bahwa tujuan ideal dari pendidikan sejarah adalah agar peserta didik mampu: Memahami sejarah, memiliki kesadaran sejarah dan memiliki wawasan sejarah. Menurut Hasan, (1994: 17-18) untuk mencapai tujuan ideal maka pelaksanaan pendidikan dan pembelajaran sejarah dijabarkan menurut taksonomi pendidikan antara lain, sebagai berikut : Kemampuan kognitif yang dikembangkan dalam pendidikan sejarah, adalah : Pengetahuan tentang peristiwa sejarah, pemahaman tentang peristiwa sejarah, kemampuan mengklarifikasi sumber sejarah, kemampuan melakukan kritik terhadap sumber sejarah, kemampuan merumuskan informasi dari sumber sejarah, kemampuan menghubungkan antar informasi, Kemampuan menggunakan hukum sebab akibat, kemampuan menggunakan berbagai istilah dan konsep, kemampuan menggunakan berbagai konsep, generalisasi, dan teori dari berbagai disiplin ilmu,kemampuan menafsirkan fakta-fakta sejarah, kemampuan menarik pelajaran dari suatu peristiwa sejarah, kemampuan bercerita tentang peristiwa sejarah.

Selain kemampuan kognitif, lebih lanjut hasan ( 1994:18-19) mengemukakan Kemampuan afektif yang dapat dikembangkan dalam pembelajaran sejarah, antara lain: Membina dan mengembangkan kesadaran berbangsa (cinta tanah air dan bangsa), mengembangkan penghargaan terhadap prestasi, memupuk keinginan untuk mengambil teladan dari tokoh-tokoh sejarah, memupuk saling pengertian, mengembangkan inisiatif dan gemar membaca. 
Hal senada diungkapkan oleh Hasan (1996) bahwa pelaksanaan pembelajaran sejarah perlu mempertimbangkan beberapa hal sebagai berikut : Pendekatan yang dikembangkan dalam pendidikan sejarah perlu mempertimbangkan tiga dimensi waktu sejarah : masa lalu, masa kini, dan masa yang akan datang sebagai kontinuitas dalam suatu hubungan kausalitas. Proses pembelajaran sejarah harus memberikan kemungkinan bagi peserta didik untuk memahami apa yang terjadi di lingkungan sekitarnya. Proses pembelajaran sejarah harus memberikan kesempatan kepada peserta didik untuk mengembangkan wawasan bahwa cerita sejarah yang mereka pelajari merupakan hasil rekontruksi sejarawan berdasarkan kaidah-kaidah ilmu sejarah. Proses pembelajaran sejarah perlu dikembangkan dengan menggunakan pendekatan lain, seperti politik, ekonomi, sosial, budaya, agama, dan ilmu pengetahuan dan teknologi. Proses pembelajaran sejarah perlu juga memunculkan isu-isu kontroversi sesuai dengan tujuan pembelajaran yang ditetapkan.

Hubungan sejarah dan pendidikan sangat erat sekali terutama dengan proses pewarisan nilai, yakni nilai-nilai luhur yang dikembangkan oleh generasi terdahulu yang perlu diwarisikan pada generasi masa kini. Proses pewarisan nilai sangat penting untuk membangun kepribadian, dan untuk mempersiapkan diri dalam menghadapi tantangan pada masa kini dan masa yang akan datang. Sejarah dapat kita pahami sebagai sekumpulan pengalaman hidup manusia pada masa lampau dalam bentuk kisah, baik lisan maupun tulisan. Pengalaman-pengalaman hidup manusia yang diabadikan dalam bentuk kisah sejarah tersebut akan sangat berharga bagi kehidupan manusia, baik pada masa kini maupun pada masa yang akan datang. Pendidikan tidak akan mungkin dapat diselenggarakan tanpa dukungan dari sejarah.

Melalui pembelajaran sejarah yang baik dan efektif diharapkan lulusan pendidikan sejarah dipersiapkan untuk menjadi pengajar atau guru sejarah. Namun selain bekerja di dunia pendidikan terutama pengajar atau guru sejarah, lulusan program studi pendidikan dapat juga bekerja di dunia non pendidikan salah satunya menjadi tour guide atau pemandu wisata sejarah. Oleh karena itu perlu pengembangan kurikulum pendidikan sejarah terutama untuk memenuhi tuntutan kebutuhan masyarakat dan untuk menjawab tantangan zaman pada masa kini.

\section{Pembahasan}

Kurikulum merupakan seperangkat rencana dan pengaturan mengenai tujuan, isi dan bahan pelajaran serta cara yang digunakan sebagai pedoman penyelenggaraan kegiatan 602 | Seminar Nasional Sejarah ke 4 Jurusan Pendidikan Sejarah Universitas Negeri Padang 
pembelajaran untuk mencapai tujuan pendidikan tertentu. Rendahnya kualitas pendidikan Indonesia seringkali dianggap sebagai akibat kegagalan kurikulum.. Selanjutnya Menteri Pendidikan dan Kebudayaan juga menilai rendahnya kualitas pendidikan di Indonesia. Mempertimbangkan kompleksitas dimulainya pembenahan pendidikan (Kompas, 2018). Pembenahan pendidikan paling ideal dimulai melalui pembenahan kurikulum.

Pengertian Kurikulum Pendidikan Tinggi menurut UU No. 12/2012 tentang Pendidikan Tinggi (Pasal 35)

1. Merupakan seperangkat rencana dan pengaturan mengenai tujuan, isi, dan bahan ajar serta cara yang digunakan sebagai pedoman penyelenggaraan kegiatan pembelajaran untuk mencapai tujuan Pendidikan Tinggi.

2. Dikembangkan oleh setiap Perguruan Tinggi dengan mengacu pada Standar Nasional Pendidikan Tinggi untuk setiap Program Studi yang mencakup pengembangan kecerdasan intelektual, akhlak mulia, dan keterampilan.

3. Dilaksanakan melalui kegiatan kurikuler, kokurikuler, dan ekstrakurikuler

Adapun fungsi kurikulum dalam perguruan tinggi yakni sebagai pedoman yang menghasilkan sistem pengajaran dan pembelajaran.

Menurut Umamah (2012) kurikulum merupakan upaya vital karena kurikulum harus selalu diupdate untuk menjawab tantangan jaman. Selain vital, kurikulumjuga dilematis karena: (1) Secara filosofi, perubahan kurikulum memberi peluang terjadinya perdebatan paradigma filsafat yang akan diadaptasi dalam pengembangannya; (2) Secara epistemologi, keilmuan pendidikan di Indonesia, sebagai penciri kurikulum, belum memiliki bangunan kokoh yang bercirikan Indonesia dengan dasar filsafat pancasila; (3) Secara kelembagaan, 5 lembaga pendidikan (keluarga, sekolah, lembaga agama, pramuka dan media) sebagai pendesain dan pelaksana kurikulum belum memiliki sinergisitas dalam mendidik anak bangsa, bahkan keberadaan seringkali kontroversial; (4) Secara Sosio-Antropologis, keanekaragaman suku dan budaya, masih diwarnai prasangka; (5) Secara empiris dijumpai kesenjangan kualitas kompetensi sumber daya manusia pelaku pendidikan. 
Kurikulum harus berubah sesuai dengan tuntutan jaman. Saat ini Negara dan Bangsa Indonesia sedang menghadapi Revolusi Industri 4.0. Realita ini bisa menjadi peluang sekaligus ancaman. Revolusi industri 4.0 menjadikan teknologi informasi sebagai kebutuhan paling urgen dalam kehidupan manusia

\section{Pengembangan Kurikulum Pendidikan Sejarah Pada Perguruan Tinggi}

Kurikulum pendidikan sejarah pada perguruan tinggi, berkembang seiring dengan perubahan kebijakan kurikulum pendidikan tinggi. Pengembangan KKNI berupaya untuk mewujudkan mutu dan jati diri bangsa Indonesia dalam sektor sumber daya manusia yang dikaitkan dengan program pengembangan sistem pendidikan dan pelatihan secara nasional. Setiap tingkat kualifikasi yang dicakup dalam KKNI memiliki makna dan kesetaraan dengan capaian pembelajaran yang dimiliki setiap insan pekerja Indonesia dalam menciptakan hasil karya dan kontribusi yang bermutu di bidang pekerjaannya masing-masing (Laman KKNI, Ristekdiki).

Menristekdikti (2018) menjelaskan ada lima elemen penting yang dapat mendorong pertumbuhan ekonomi dan daya saing bangsa di era Revolusi Industri 4.0, yaitu:

1. Persiapan sistem pembelajaran yang lebih inovatif di perguruan tinggi seperti penyesuaian kurikulum pembelajaran, dan meningkatkan kemampuan mahasiswa dalam hal data Information Technology (IT), Operational Technology (OT), Internet of Things (IoT), dan Big Data Analitic, mengintegrasikan objek fisik, digital dan manusia untuk menghasilkan lulusan perguruan tinggi yang kompetitif dan terampil terutama dalam aspek data literacy, technological literacy and human literacy.

2. Rekonstruksi kebijakan kelembagaan pendidikan tinggi yang adaptif dan responsif terhadap revolusi industri 4.0 dalam mengembangkan transdisiplin ilmu dan program studi yang dibutuhkan. Selain itu, mulai diupayakannya program Cyber University, seperti sistem perkuliahan distance learning, sehingga mengurangi intensitas pertemuan dosen dan mahasiswa. Cyber University ini nantinya diharapkan menjadi solusi bagi anak bangsa di pelosok daerah untuk menjangkau pendidikan tinggi yang berkualitas.

3. Persiapan sumber daya manusia khususnya dosen dan peneliti serta perekayasa yang responsif, adaptif dan handal untuk menghadapi revolusi industri 4.0. Selain itu, peremajaan sarana prasarana dan pembangunan infrastruktur pendidikan, riset, dan inovasi juga perlu dilakukan untuk menopang kualitas pendidikan, riset, dan inovasi. 
4. Terobosan dalam riset dan pengembangan yang mendukung Revolusi Industri 4.0 dan ekosistem riset dan pengembangan untuk meningkatkan kualitas dan kuantitas riset dan pengembangan di Perguruan Tinggi, Lembaga Litbang, LPNK, Industri, dan Masyarakat

5. Terobosan inovasi dan perkuatan sistem inovasi untuk meningkatkan produktivitas industri dan meningkatkan perusahaan pemula berbasis teknologi.

Dalam kurikulum pendidkan sejarah di perguruan tinggi, capaian pembelajaran lulusan (Learning Outcomes) merupakan rumusan untuk mencapai standar kompetensi lulusan merupakan kriteria minimal tentang kualifikasi kemampuan lulusan yang mencakup sikap, pengetahuan dan keterampilan. Capaian pembelajaran lulusan selain berfungsi untuk mendukung profil lulusan program studi juga digunakan sebagai acuan utama pengembangan standar isi pembelajaran, standar proses pembelajaran, standar penilaian pembelajaran, standar dosen dan tenaga kependidikan, standar sarana dan prasarana pembelajaran,standar pengelolaan pembelajaran dan standar pembiayaan pembelajaran.

Rumusan capaian pembelajaran lulusan mengacu pada deskripsi capaian pembelajaran lulusan KKNI level 6.

\section{Sikap}

a. Bertakwa kepada Tuhan Yang Maha Esa dan mampu menunjukkan sikap religius

b. Menjunjung tinggi nilai-nilai kemaanusiaan dalam menjalankan tugas berdasarkan agama, moral dan etika

c. Menginternalisasi nila,norma, dan etika akademik

d. Berperan sebagai warga negara yang bangga dan cinta tanah air

e. Menghargai keanekaragaman budaya,pandangan,agama,dan kepercayaan serta pendapat atau temuan orisinal orang lain

f. Berkontribusi dalam peningkatan mutu kehidupam masyarakat, berbangsa, bernegara, dan kemajuan peradaban berdasarkan pancasila

g. Bekerjasama dan memiliki kepekaan sosial serta kepedulian terhadap masyarakat dan lingkungan

h. Taat hukum dan disiplin dalam kehidupan bermasyarakat dan bernegara

i. Menginternalisasikan semangat kemandirian, kejuangan dan kewirausahaan 
j. Menunjukkan sikap bertanggungjawab atas pekerjaan di bidang keahliannya secara mandiri

Capaian pembelajaran khusus

a. Menunjukkan perilaku yang sesuai dengan norma agama, hukum, sosial, dan kebudayaan nasional Indonesia

b. Berkomunikasi secara efektif, empatik, dan santun dengan peserta didik

c. Berperilaku yang mencerminkan budaya Jawa (indigenius)

d. Membangun jaringan dalamkegiatan interpreneurship

e. Berjiwa wirausaha dan berani memulai bisnis secara mandiri

f. Mampu mengembangkan dan mengaplikasikan ide-ide kreatif

g. Memiliki jiwa interpreneur yang berbasis Lab.sejarah

h. Mampu bekerja secara cermat,teliti dan tanggung jawab

i. Bekerjasama dengan kolega

\section{Pengetahuan}

Pengetahuan merupakan penguasaan konsep, metode, dan /atau falsafah bidang ilmu prodi secara sistematis yang diperoleh melalui penalaran dalam proses pembelajaran, pengalaman kerja mahasiswa, penelitian dan/ atau pengabdian kepada masyarakat yang terkait pembelajaran.

a. Mampu menguasai konsep dan toeri kependidikan

b. Mampu menguasai karakteristik peserta didik dari aspek fisik, moral, spiritual, sosial, kultural, emosional dan intelektual untuk memaksimalkan proses dan hasil belajar

c. Mampu menguasai teori belajar dan prinsip - prinsip pembelajaran yang mendidik

d. Mampu menguasai materi tentang sejarah Indonesia berdasarkan periodisasi

e. Mampu menguasai materi tentang sejarah Eropa, Asia, Afrika, Amerika dan Australia yang mendukung mata pelajaran sejarah

\section{Ketrampilan Umum dan Ketrampilan Khusus}

Ketrampilan merupakan kemampuan melakukan unjuk kerja dengan menggunakan konsep, teori, metode, bahan, dan/atau instrumen, yang diperoleh melalui pembelajaran, pengalaman, kerja mahasiswa, penelitian dan/atau pengabdian kepada masyarakat yang terkait pembelajaran, mencakup : ketrampilan umum dan ketrampilan khusus.

\section{Ketrampilan umum mencakup :}


1. Mampu menerapkan pemikiran logis, kritis, sistematis dan inovatif dalam bidang ilmu dan/atau teknologi di bidang keahliannya

2. Mampu mengkaji pengetahuan dan/atau teknologi di bidang keahliannya berdasarkan kaidah keilmuan, atau menghasilkan karya desain/ seni beserta deskripsinya berdasarkan kaidah atau metode rancangan baku, yang disusun dalam bentuk skripsi atau laporan tugas akhir

3. Mampu mempublikasikan hasil tugas akhir atau karya desain/ seni yang memenuhi syarat tata tulis ilmiah dan dapat diakses oleh masyarakat akademik

4. Mampu menyusun dan mengkomunikasikan ide dan informasi bidang keilmuannya secara efektif, melalui berbagai bentuk media kepada masyarakat akademik

\section{Ketrampilan khusus mencakup sebagai berikut :}

1. Mampu menyelenggarakan pembelajaran sejarah yang inovatif

Mampu menyelenggarakan penilaian dan evaluasi proses dan hasil belajar sejarah

2. Mampu memanfaatkan teknologi informasi untuk menguasai media pembelajaran sejarah

3. Mampu mengembangkan materi pembelajaran sejarah secara kreatif, inovatif dan reflektif

4. Mampu menguasai berbagai metode pembelajaran sejarah

5. Mampu merancang, melaksanakan dan mengevaluasi pembelajaran sejarah di sekolah

6. Mampu melaksanakan prosedur penelitian untuk kepentingan pengembangan proses pembelajaran sejarah

7. Mampu mengelola administrasi pembelajaran

8. Mampu merancang, melaksanakan, dan mengevaluasi penelitian sejarah

Kemampuan umum sebagai kemampuan kerja umum yang wajib dimiliki oleh setiap lulusan dalam rangka menjamin kesetaraan kemampuan lulusan sesuai tingkat program dan jenis pendidikan tinggi sedangkan kemampuan khusus sebagai kemampuan kerja khusus yang wajib dimiliki oleh setiap lulusan sesuai dengan bidang keilmuan program studi pendidikan sejarah.

\section{Pengembangan Materi Tour guide Dalam kurikulum pendidikan sejarah}

Kurikulum pendidikan sejarah dalam perguruan tinggi,terdapat materi-materi yang perlu dikembangkan diantaranya materi tour guide. Hal ini disebabkan karena lulusan pendidikan sejarah selain dipersiapkan menjadi pengajar namun juga dapat bekerja di luar pendidikan seperti tour guide. Materi tour guide pendidikan sejarah ruang lingkup materinya meliputi, profesi tour 
guide (pramuwisata), layanan pemanduan wisata, informasi Tour, Jenis-jenis tour guide, tempat tujuan wisata.

Secara garis besar materi tour guide dapat dijabarkan sebagai berikut:

a. Pengertian Tour guide

Tata Nuriata (1995:1) pramuwisata berasal dari bahasa Sansekerta yaitu pramu, wis dan ata. Pramu berarti pelayan atau orang yang melayani, wis berarti tempat dan ata berarti banyak. Wisata diartikan sebagai keliling atau perjalanan sehingga dalam hal inipramuwisata dapat dikatakan sebagai petugas yang melayani orang yang sedang melakukan perjalanan wisata.

Menurut Menparpostel : Pramuwisata adalah " seseorang yang bertugas memberikan bimbingan, penjelasan dan petunjuktentang obyek wisata serta membantu keperluan wisatawan lainnya.

Menurut Oka.A.Yoeti pramuwisata adalah seorang yang member penerangan, penjelasan serta petunjuk kepada wisatawan dan traveler lainnya,tentang segala sesuatu yang hendak dilihat dan disaksikan bilamana mereka berkunjung pada suatu obyek, tempat atau daerah.

Pramuwisata adalah seorang yang bekerja untuk wisatawan, biro perjalanan, ataupun lembaga kepariwisataan lain untuk memberikan informasi,memimpin perjalanan atau memberi saran-saran kepada wisatawan sebelum atau selama kunjungan-kunjungan singkatnya.

Pramuwisata merupakan salah satu profesi yang unik, karena profesi ini membutuhkan kemampuan berbahasa sesuai yang dibutuhkan, dapat berinteraksi dengan wisatawan, memiliki pengetahuan luas, fleksibel, penuh pengertian dan kedewasaan berpikir serta sehat jasmani dan rokhani serta. mampu dan pengalaman dalam memandu wisata.

b. Kode etik Pramuwisata Indonesia

1. Seorang pramuwisata harus memberi kesan yang baik mengenai kebudayaan, agama dan negara

2. Seorang pramuwisata harus menjaga penguasaan diri yang tinggi dan memperhatikan penyajian pribadi termasuk kebersihan dan penampilan

3. Seorang pramuwisata harus sanggup menciptakan suasana yang hangat dan gembira dan sopan santun yang mencerminkan budaya Indonesia

c. Peran, tanggung jawab dan hak Pramuwisata 
Dalam melaksanakan tugasnya, pramuwisata harus memahami batasan-batasan wewenang dan tanggung jawab sesuai dengan perjanjian kerja/peraturan/job diskripsi yang berlaku pada perusahaan tempat dia bekerja dan mentaati kode etik pramuwisata.

Pekerjaan pemanduan adalah pekerjaan yang dituntut untuk membina jejaring kerja antar perusahaan pemasok jasa yang terkait dengan layanan pemanduan wisata, antara lain: Perusahaan (Biro Perjalanan), Para penyedia pelayanan tour, Teman-teman sejawat industry, para peserta tour/wisatawan Masyarakat lokal (pertimbangan kebudayaan dan lingkungan), Diri sendiri, Memahami hal-hal yang berhubungan dengan asuransi perjalanan,

d. Fungsi dan Uraian Tugas Pramuwisata

Fungsi tour guide antara lain :

1. Membimbing perjalanan bersama wisatawan untuk mencapai tujuan yang telah ditentukan sesuai dengan tugas pramuwisata

2. Memberikan informasi, bila perlu menjadi penterjemah mengenai perjalanan secara keseluruhan khususnya mengenai obyek-obyek wisata yang dikunjungi

3. Memperkenalkan hal-hal yang dirasakan baru bagi wisatawan atau yang perlu diketahui serta dijumpai selama perjalanan

4. Memberikan saran kepada wisatawan untuk melakukan sesuatu tindakan atau kegiatan yang mungkin timbul dan ada sangkut pautnya dengan perjalanan yang sedang dipandunya.

Uraian Tugas pariwisata antara lain :

Memahami isi dan fasilitas yang tertera dalam paket wisata, Memeriksa kelengkapan dokumen-dokumen perjalanan wisata, Mengantar wisatawan baik rombongan maupun perorangan yang mengadakan perjalanan dengan alat transportasi, Memberikan penjelasan tentang rencana perjalanan wisata dan destinasi serta peraturan-peraturan/ ketentuan mengenai; visa, paspor, keterangan kesehatan,akomodasi, transportasi dan lain sebagainya

e. Jenis-Jenis tour guide

jenis-jenis tour guide dapat dikelompokkan sebagai berikut:On-site guide, City Tour Guide ,city guide disebut dengan personal atau private guide dan Specialized guide

Selain materi tour guide yang telah dijelaskan diatas, terdapat materi tour guide yang diarahkan ke bagian kesejarahan, karena bangsa Indonesia sangat kaya sekali akan peningggalan 
khasanah budaya serta peristiwa dan tempat yang perlu dikunjungi. Dengan mengunjungi tempat-tempat bersejarah sudah barang tentu dapat menumbuhkan dan menanamkan jiwa nasionalisme pada bangsa Indonesia. Oleh karena itu perlu adanya pengembangan materi tour guide terutama dalam bidang kesejarahan.

\section{Simpulan}

Rendahnya kualitas pendidikan Indonesia seringkali dianggap sebagai akibat kegagalan kurikulum. Kurikulum harus berubah sesuai dengan tuntutan zaman. Kurikulum dalam pendidikan sejarah seyogyanya perlu pengembangan materinya, hal ini karena tuntutan masyarakat zaman sekarang. Oleh karena itu Lulusan pendidikan sejarah dipersiapkan untuk menjadi pengajar atau guru sejarah. Namun selain bekerja di dunia pendidikan terutama pengajar atau guru sejarah, lulusan program studi pendidikan dapat juga bekerja di dunia non pendidikan salah satunya menjadi tour guide atau pemandu wisata sejarah.

Materi Tour guide juga bermanfaat terutama bagi mahasiswa yang mencari sertifikat pendamping ijasah bagi kelulusannya sehingga mahasiswa harus magang. Dengan dibekali materi tour guide mahasiswa dapat melaksanakan magang secara optimal.

\section{DAFTAR PUSTAKA}

Abdullah, T. 2001. Nasionalisme \& Sejarah. Bandung: Satya Historika.

Hariyono. 2012. Pendidikan Sejarah dan Karakter Bangsa.

Hasan H. S. 2007. Kurikulum Pendidikan Sejarah Berbasis Kompetensi. Seminar Pendidikan Sejarah di Jurusan Sejarah UNNES.

Hasan, H. (2010). Pendidikan Sejarah: Kemana dan Bagaimana?. Disajikan pada seminar Asosiasi Guru Sejarah Indonesia (AGSI), Jakarta, 6 Maret 2010

Menristekdikti (2018) https://www.ristekdikti.go.id/pengembangan-iptek-dan pendidikan-tinggidi-era-revolusi-industri-4-0 2/\#AWDcVe62e6B4GLJW.99 diakses 9 April 2019

Kemendikbud. 2013. Kerangka Dasar dan Kurikulum 2013. Jakarta: Kemendikbud

Laman KKNI, Ristekdikti. Tanpa Tahun. Kerangka Kualifikasi Nasional Indonesia. http://kknikemenristekdikti.org/paradigma diakses pada 9 April 2019 
National Center for History in the School. 1996. Historical Analysis and interpretation. Retrieved from http://www.nchs.ucla.edu/history-standards/historicalthingkingstandards/3-historical-analysis-and-interpretation.

Ozmen dan Kizilay. 2017. A Study on the Historical analysis Skills of Social Studies and Classroom Teachers. Turkey: Universitepark Bulten, 6(1), 133-148.

UU Nomor 12 Tahun 2012 Tentang Pendidikan Tinggi Pasal 25

Peraturan Menteri Pendidikan dan Kebudayaan RI No. 79 Tahun 2014

Umamah, N. 2012. "Rekonstruksi Kurikulum Upaya Vital yang Dilematis" dalam Prosiding Seminar Nasional Rekonstruksi Kurikulum Berbasis Karakter Dalam menyongsong Pemberlakuan Kurikulum 2013. Program Studi Pendidikan Sejarah Universitas Jember, 42-54

Sartono Kartodirdjo, 1994. Kebudayaan Pembangunan dalam Perspektif Sejarah.Yogyakarta:Gadjah Mada University Press.

Supardi. 2006. Pendidikan Sejarah Lokal Dalam Konteks Multikulturalisme. Cakrawala Pendidikan. Februari 2006. Th XXV. No. 1

Widja, I Gde. 1989. Dasar-dasar Pengembangan Strategi Serta Metode Pengajaran Sejarah. Jakarta: Depdikbud Dirjen Dikti Proyek Pengembangan LPTK. 